\title{
"CINEMA QUARENTENOLÓGICO": UMA EXPERIÊNCIA NOVA DE TROCA DE APRENDIZADOS SOBRE O CULTIVO DA UVA E A CULTURA DO VINHO
}

\author{
Mariana de Vasconcellos Dullius - http://orcid.org/0000-0003-2379-94601 \\ Ana Carolina Almeida Lima Macedo - http://orcid.org/0000-0002-7324-76672 \\ Sâmia Haddock Lobo - http://orcid.org/0000-0002-4458-3063³
}

\section{RESUMO}

Buscando estratégias de correlacionar conteúdos científicos, técnicos e tecnológicos, o "Cinema Quarentenológico: aprendendo sobre Viticultura e Enologia em tempos de pandemia por meio de filmes e documentários" teve por objetivo discutir temáticas relacionadas com a cultura da uva e do vinho retratadas dentro de contextos históricos de relevância mundial. Em oito encontros virtuais, reuniram-se enófilos, cinéfilos e, de forma geral, interessados em aprender mais sobre viticultura e enologia. Trabalharam-se, por meio de atividades síncronas e assíncronas, sete roteiros de cinema, os quais, numa construção crítica e participativa, foram discutidos do ponto de vista técnico, tecnológico e científico, sem que se deixassem passar os aspectos históricos inerentes a eles. A reconstrução do espaço de ensino e aprendizagem imposta pela pandemia do novo coronavírus permitiu a participação de pessoas de todo o Brasil, e a diversidade do público atendido contribuiu para o enriquecimento do diálogo, explorando a multidisciplinaridade e a pluralidade de ideias.

Palavras-chave: aprendizado em tempos de pandemia; democratização da cultura da uva e do vinho; formação profissional e cidadã; enografia; cinema e educação.

1 Doutoranda em Ciências Biológicas-Bioquímica pela Universidade Federal do Rio Grande do Sul, Professora do IFSC-Câmpus Urupema. E-mail: mariana.dullius@gmail.com

2 Estudante do Curso Técnico em Agricultura do IFSC-Câmpus Urupema. E-mail: lima.anacarolins17@gmail.com

3 Graduanda em Tecnologia em Viticultura e Enologia do IFSC-Câmpus Urupema. E-mail: samiah.lobo@gmail.com 


\title{
Cinema Quarentenológico: a New Experience in Learning Exchange about Growing Grapes and Wine Culture
}

\author{
ABSTRACT
}

The outreach activity named“Cinema Quarentenológico: Learning about Viticulture and Oenology in Times of Pandemic through Films and Documentaries" sought strategies to correlate scientific, technical, and technological content. Also, it aimed to discuss themes related to the culture of grapes and wines that are portrayed in contexts of great relevance to the world history. Oenophiles, moviegoers, and people in general interested in learning more about Viticulture and Oenology joined to discuss movie scripts which have wine as subject. The group had eight virtual meetings and worked on seven scripts through asynchronous and synchronous activities. The discussion about the scripts took place from a technical, technological, and scientific point of view in a critical and participatory construction, and kept in mind the historical aspects that serve as backdrops for the stories. The reconstruction of the teaching and learning environment imposed by the new coronavirus pandemic situation allowed the participation of people from all over Brazil. Such diversity of partakers contributed to the enrichment of the dialogue by profiting on the multidisciplinarity and plurality of ideas.

Keywords: learning in times of pandemic; democratization of grape and wine culture; professional and citizen training; Oenography; Cinema and Education.

\section{INTRODUÇÃO}

Quando se teve a ideia de realizar um curso de extensão que aliasse o cinema, a uva e o vinho, o Brasil registrava 84 mil mortes confirmadas pelo novo coronavírus (SARSCoV-2) (BRASIL, 2020), e já parecia que estratégias de ensino remoto seriam multiplicadas num futuro iminente. Seis meses depois, quando por ocasião da redação deste artigo, o país já ultrapassava as 217 mil mortes em decorrência da COVID-19 (BRASIL, 2021). Desde o início da pandemia, o ensino remoto aprimorou-se, até mesmo como consequência imediata da necessidade de se reinventarem estratégias para o ensino e a aprendizagem.

A tática de unir cinema e ciência já é uma velha conhecida de educadores. Vargas e Lopes (2020) mostraram a importância de mediar a construção de conhecimento científico e de tornar as aulas mais lúdicas a partir da análise crítica de filmes da franquia Star Wars, enfatizando o aspecto positivo que os erros científicos têm na construção do 
conhecimento em si. Na medida em que a sala de aula é descentralizada, e que o aluno passa a ser protagonista do seu aprendizado, o professor assume o papel de facilitador, de mediador do aprendizado, sendo que cabe ao discente construir ativamente o conhecimento (VARGAS; LOPES, 2020). Esse aspecto da descentralização, se bem conduzido pelo docente, torna-se elemento cognitivo importante a ser explorado com o ensino remoto durante a pandemia.

O cinema nasceu em 1893, pelas mãos de Thomas Edison - que, ao criar um mecanismo intermitente de projeção, permitiu a primeira exibição sequencial de imagens através de um cinetoscópio de uso individual - e fora aperfeiçoado até 1895, quando os irmãos Lumière proporcionaram, a um público pagante, a primeira projeção de imagens no que chamaram de cinematógrafo (MASCARELLO, 2015). De lá para cá, não só as tecnologias cinematográficas evoluíram, como também o cinema se tornou instrumento de produção crítica social e espaço para o exercício da liberdade criativa (MASCARELLO, 2015), para as construções do imaginário, para a aferição de sensibilidades e de práticas sociais e, ainda, lugar de representação (SCHVARZMAN, 2007). Essa dinâmica de debater, de pensar e de refletir em grupo sobre um filme é denominada de cineclubismo e, no Brasil, tal atividade teve início em 1928, com a criação do Chaplin Club, no Rio de Janeiro (BUTRUCE, 2011). 
Figura 1 - Distribuição de salas de cinema nos municípios brasileiros

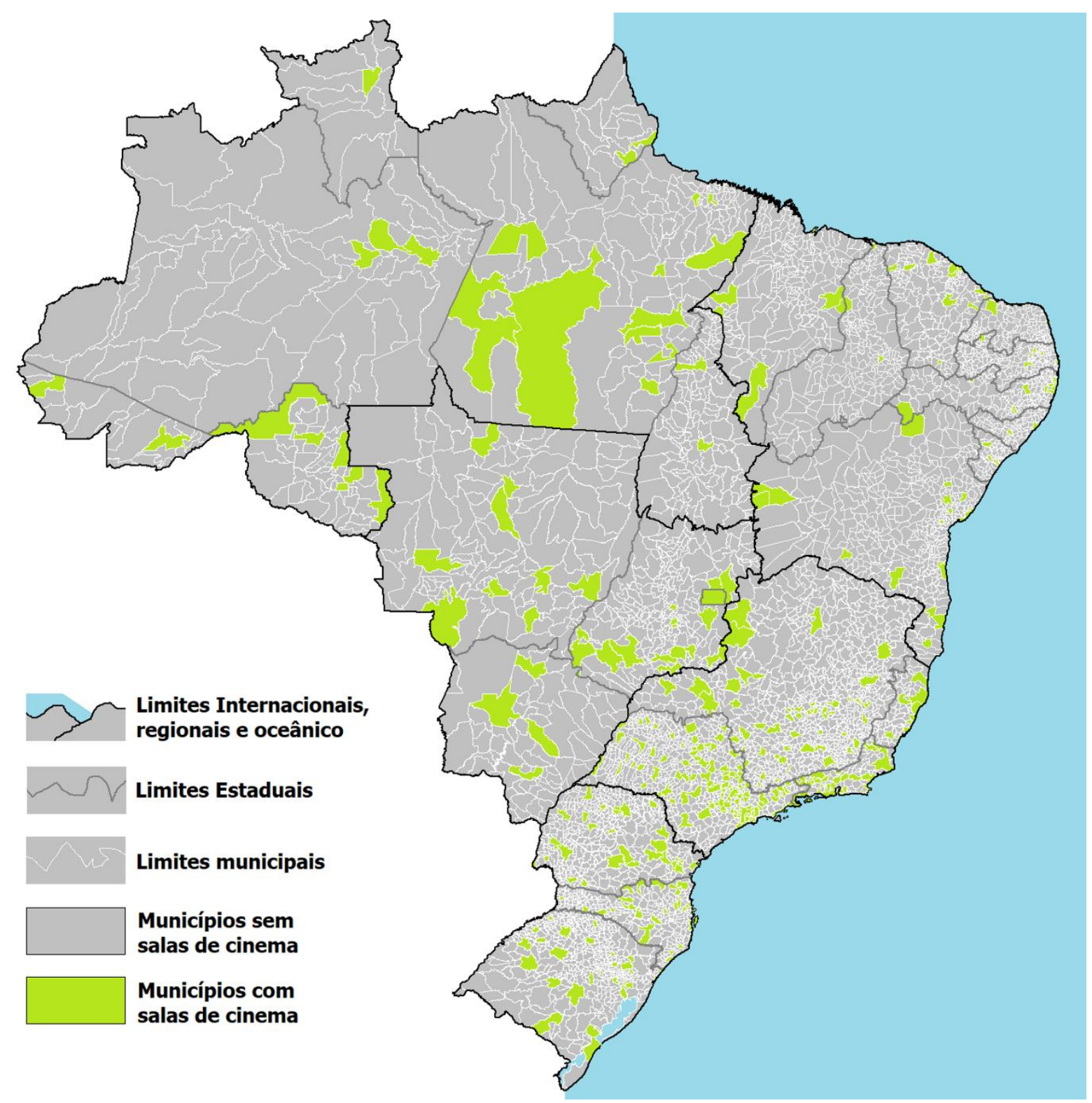

Fonte: Elaborada pelas autoras a partir de dados disponíveis no Observatório Brasileiro do Cinema e do Audiovisual (OCA-ANCINE, 2018).

Dados do Observatório Brasileiro do Cinema e do Audiovisual revelam que o Brasil contava com 3.352 salas de cinema em 2018 (OCA-ANCINE, 2018); contudo, a distribuição dessas salas pelo país não é homogênea. Há 5.572 municípios no Brasil (IBGE, 2019), porém as salas de cinema estão concentradas em apenas 7,4\% desses (Figura 1), sendo que, apenas nas regiões Sul e Sudeste do país, consegue-se observar uma cobertura mais ampla dos territórios estaduais com espaços próprios para essa forma de cultura.

Figura 2 - Quantidade de salas de cinema por estados brasileiros 


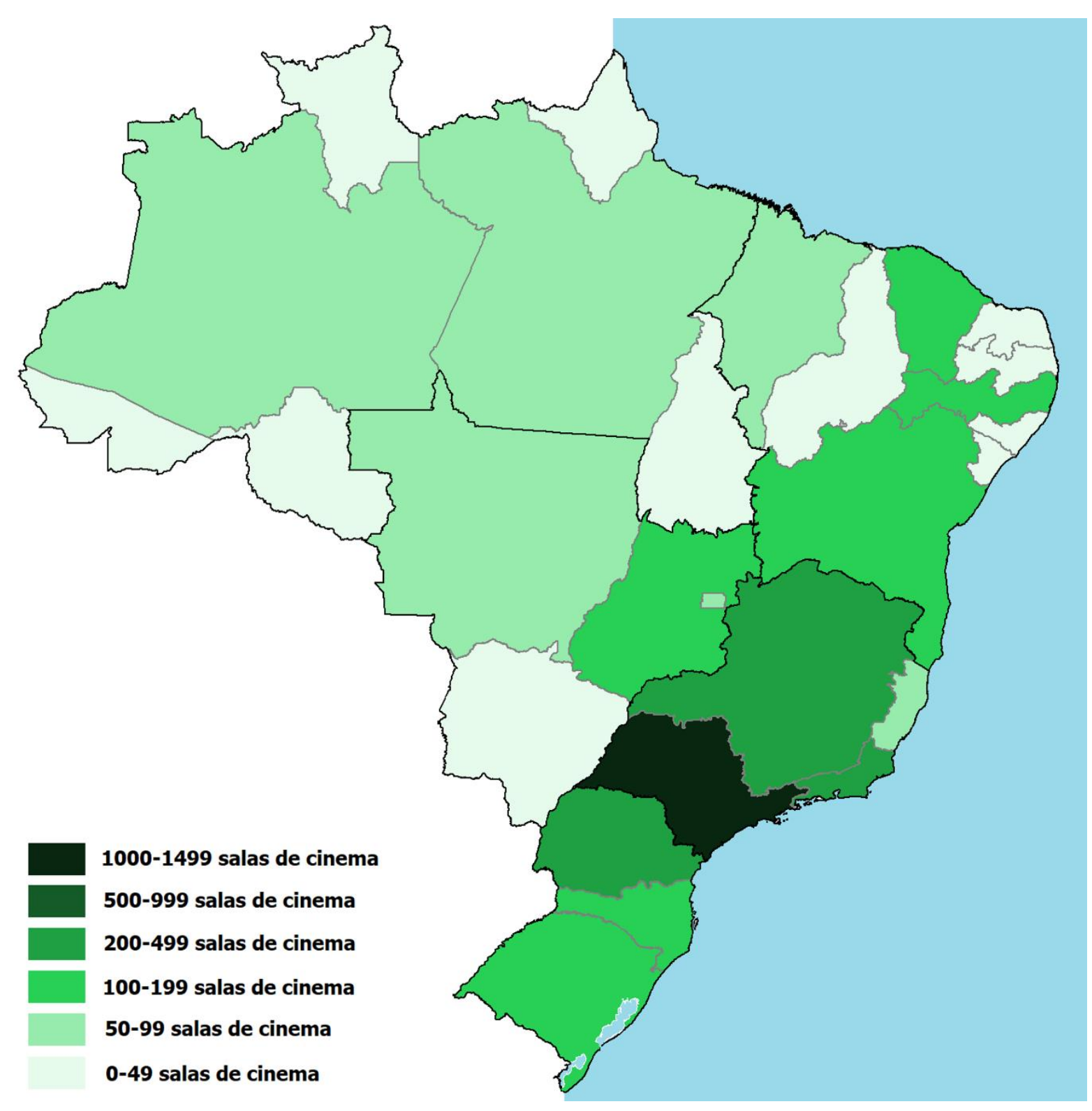

Fonte: Elaborada pelas autoras a partir de dados disponíveis no Observatório Brasileiro do Cinema e do Audiovisual (OCA-ANCINE, 2018).

O número de salas de cinema (Figura 2) é superior onde há maior densidade populacional, havendo estados brasileiros em que a oferta acontece apenas nas capitais, como no caso de Roraima e Amapá, ou em até um município do interior, além da capital, como no caso do Acre, Alagoas e Rio Grande do Norte.

A cidade brasileira com a maior oferta de salas de cinema é a capital federal, Brasília-DF, mas, quando se avalia o equilíbrio da distribuição da oferta, Vitória (19\%) e Florianópolis (14\%) são as capitais que concentram menos salas (Figura 3), abrindo espaço para a cultura do cinema no interior do país.

Figura 3 - Concentração de salas de cinema nas capitais do país e no Distrito Federal 


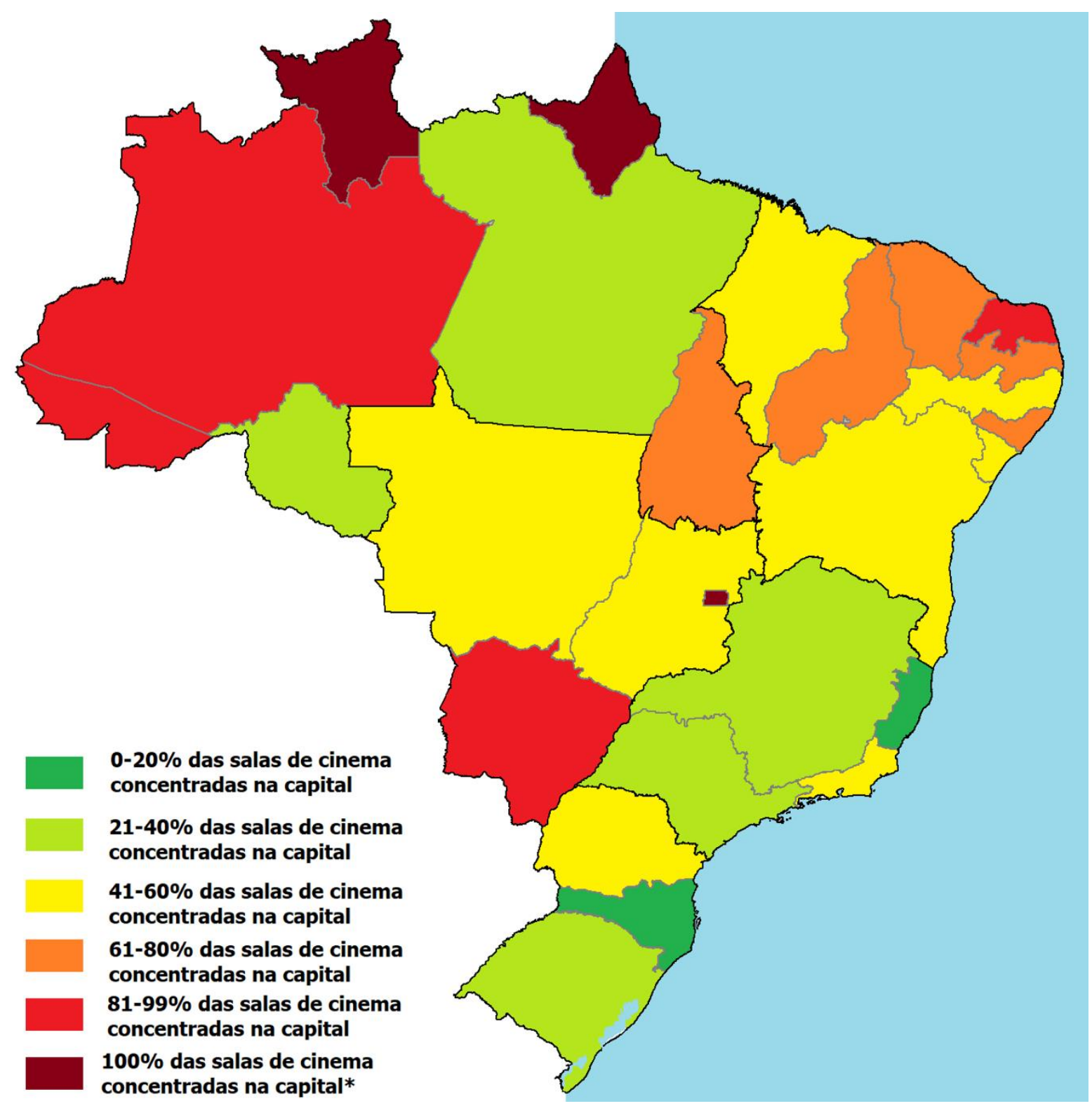

Fonte: Elaborada pelas autoras a partir de dados disponíveis no Observatório Brasileiro do Cinema e do Audiovisual (OCA-ANCINE, 2018).

Em março de 2020, contudo, a pandemia causou o fechamento de salas de cinema em larga escala em todo o mundo, não sendo diferente no Brasil. O Sistema de Controle e Bilheteria (SIC) registrou que, em abril de 2020, não havia mais do que cinco salas em funcionamento no país (ANCINE, 2021). Em uma pesquisa do Datafolha, de todas as atividades culturais limitadas pela pandemia, 30\% dos brasileiros sentiram mais falta do cinema, e 44\% dos que consideram retornar seus planos culturais pretendiam incluir a ida ao cinema entre as suas prioridades (MOURA, 2020).

A viticultura e a enologia são as duas ciências que dão a base para todo o conhecimento relacionado ao processo de transformação da uva em vinho. Ainda que o 
Brasil não figure entre os países com o maior consumo per capita do mundo; em termos de volume, está entre os principais mercados (ABE, 2020). Quando se analisa o montante consumido particularmente no ano de 2020, observa-se que a situação de pandemia beneficiou o mercado brasileiro de vinhos (ABE, 2020). E toda vez que cresce o consumo, aumenta também a curiosidade do público consumidor, e, por conseguinte, a necessidade de que se fale mais sobre vinhos, não só do ponto de vista dos seus benefícios, mas, e principalmente, do ponto de vista da responsabilidade na sua ingestão.

A enografia é a ciência que estuda os vinhos de uma determinada região definida geograficamente. Vinhos apresentam características resultantes da relação da planta com o solo, com o clima e com as práticas vitícolas e enológicas utilizadas na região. Estudos de enografia baseiam-se na análise de documentos históricos, de legislações, de arquivos de produtores, de cadastros de entidades reguladoras e de pesquisa dessas localidades, de estudos organolépticos dos vinhos e da verificação in loco das características relativas aos vinhedos e às vinícolas por meio de visitas e entrevistas dirigidas aos respectivos responsáveis técnicos. Também se incluem estudos socioeconômicos, gastronômicos e culturais. Quando, por meio do cineclubismo, tem-se a oportunidade de explorar esses diversos - senão todos! - elementos de forma dinâmica, interativa, envolvente, tendo como pano de fundo a própria história da humanidade, por que não o fazer?

A oferta de cursos de extensão no Instituto Federal de Santa Catarina (IFSC) apresenta como vantagem a dinâmica com que consegue atender a necessidades urgentes e emergentes, tais como as com que as instituições de ensino se depararam no ano de 2020 por consequência da crise sanitária mundial. Parte do sucesso desses cursos de curta duração também está no fato de que não necessariamente o público se interesse em, por exemplo, atuar nos processos de elaboração de vinhos, para os quais seria necessária uma formação técnica e/ou tecnológica, mas, talvez muito mais, em satisfazer suas curiosidades acerca dessa bebida milenar que cada vez ganha mais apreciadores dentre os brasileiros.

A possibilidade de que houvesse a oferta de um curso integralmente em formato remoto foi inédita para a área da viticultura e da enologia, permitindo captar interessados que, em outra modalidade, não conseguiriam participar. Embora a demanda para a oferta em si não tenha partido da comunidade, há muito que as coordenadorias pedagógicas e de cursos do câmpus Urupema registravam o interesse de público para ações pontuais de capacitação naquelas áreas do conhecimento. Sendo assim, a intenção em ofertar o curso partiu da aposta de que, de forma remota, seria possível, finalmente, acercar a expertise dos profissionais do câmpus em viticultura e enologia a públicos externos à pequena cidade de Urupema. Assim, com o intuito de atender a um público-alvo de enófilos 
(apreciadores de vinho) e de cinéfilos (apreciadores de cinema) de qualquer lugar do Brasil, a ação de extensão "Cinema Quarentenológico: aprendendo sobre Viticultura e Enologia em tempos de pandemia por meio de filmes e documentários" fora proposta.

Aproveitando o fato de que há diversos filmes e documentários que abordam a temática do vinho de alguma forma, buscou-se uma maneira de aproveitar o interesse do público em aprender mais sobre viticultura e enologia usando a estratégia de aproximar o cinema e a cultura desse mesmo público. Além disso, democratizar o conhecimento acerca da uva e do vinho é compromisso dos profissionais que trabalham na vitivinicultura, e fomentar a rede de contatos entre discentes da instituição e participantes das mais diversas áreas do setor produtivo da uva e do vinho é uma tática importante de aproximação e de inserção profissional. A ação de extensão estabeleceu como objetivos manter o vínculo de alunos que, voluntariamente e remotamente, pudessem colaborar na construção dessa dinâmica de interação entre a instituição e a comunidade; fortalecer as bases técnico-tecnológico-científicas do aprendizado em vitivinicultura dos alunos do IFSC-Câmpus Urupema e contribuir para a sua formação holística e cidadã; colaborar com estratégias de permanência e êxito dos discentes na instituição e de inserção no mercado de trabalho; e experimentar uma outra modalidade, com o ensino remoto, abordando novas formas de trabalhar velhos temas relacionados à viticultura e à enologia.

\section{Metodologia}

\subsection{Desenvolvimento do curso de extensão}

O curso foi construído dentro de um modelo híbrido de ensino-aprendizagem, constituído de oito encontros síncronos quinzenais, noturnos e de três horas de duração, com atividades assíncronas opcionais no intervalo entre os encontros. Ao longo da quinzena, o participante tinha a possibilidade de assistir aos filmes sugeridos, por quantas vezes quisesse/entendesse necessárias, para então acompanhar e participar de forma protagonista do debate, da discussão e das reflexões históricas e científicas que estavam por trás do enredo de cada roteiro, retornando ao seu próprio mundo com novas ponderações proporcionadas pelo cinema acerca de velhos problemas sobre a vitivinicultura.

Os encontros síncronos também contaram com o uso da ferramenta Mentimeter, por meio da qual sempre foram feitas duas perguntas aos participantes: "Qual a sua experiência com o filme/documentário (nome do filme ou do documentário)?" e registre "Três palavras ou expressões que o filme/documentário (nome do filme ou do documentário) deixou para ti hoje:". O primeiro questionamento era lançado aos participantes na primeira meia hora, e o 
segundo era feito ao público na última meia hora de cada encontro síncrono. A primeira indagação trazia sempre as mesmas cinco opções de respostas para os participantes: 1) não consegui assistir; 2) já tinha assistido antes, mas não consegui rever; 3) já tinha assistido antes, mas consegui rever; 4) assisti pela primeira vez agora, por causa da indicação do curso e; 5) assisti pela primeira vez agora, mas já tinham me indicado antes que o assistisse. Já a segunda pergunta permitia aos participantes a digitação de três palavras ou expressões que resumissem a relação que eles haviam tido não apenas com o filme, mas, especialmente, com o debate, com a discussão e com a reflexão gerada durante o momento síncrono.

Para que se tivessem devolutivas de cada momento síncrono, elaboraram-se questionários (QD-Fil-1, QD-Fil-2, QD-Doc-3, QD-Fil-4, QD-Fil-5, QD-Doc-6, QD-Fil-7), usando o Google Forms, que deram aos participantes chances de comentarem, de registrarem dúvidas remanescentes, de apresentarem críticas e de proporem sugestões.

Outros dois formulários foram preparados para o curso. Um primeiro, denominado de "Boas-vindas aos participantes" (QD-BVP-0), tinha por intuito coletar as informações básicas a respeito do público inscrito, tais como perfil profissional e relação com o universo da uva e do vinho, motivos de interesse para se inscrever no curso, conhecimentos anteriores sobre viticultura e enologia, sugestão de plataforma para o desenvolvimento dos momentos síncronos, relação do participante com o IFSC. Um segundo formulário, denominado “Avaliação Geral do Curso" (QD-AGC-8), foi aplicado após a ocorrência dos oito encontros e teve por objetivo coletar as percepções globais da ação executada, incluindo aspectos relacionados ao conteúdo, à docência, ao protagonismo discente voluntário e à metodologia adotada.

Por fim, para facilitar a comunicação com os participantes, propôs-se, no primeiro encontro, a criação de um grupo no aplicativo WhatsApp, com adesão voluntária. Os canais de comunicação formais seguiriam sendo o e-mail institucional da coordenação do curso, os formulários criados para a atividade e os espaços proporcionados pelas atividades síncronas; contudo, o grupo de WhatsApp contribuiu como suporte à interação entre equipe e participantes.

\subsection{Escolha dos filmes e documentários}

Como o primeiro encontro seria dedicado à apresentação do curso e da metodologia, bem como a proporcionar a interação entre os participantes e a equipe, sete roteiros, incluindo cinco filmes e dois documentários, foram selecionados para serem trabalhados nos demais momentos. 0 menor número de documentários deu-se pelo fato de que estes geralmente exigem maior atenção, pois possuem maior riqueza de 
informação e ausência ou baixa presença de elementos que dão ritmo à estória, tais como música e fotografia. Os documentários foram estudados intercalados aos filmes também como estratégia didática.

A filmografia incluiu os seguintes roteiros: 1) A Walk in the Clouds (trad. Caminhando nas Nuvens, 1995); 2) Bottle Shock (trad. O Julgamento de Paris, 2008); 3) Sour Grapes (trad. Uvas Azedas, 2016); 4) The Secret of Santa Vittoria (trad. O Segredo de Santa Vittoria, 1969); 5) A Good Year (trad. Um Bom Ano, 2006); 6) The Truth about Alcohol (trad. A Verdade sobre o Álcool, 2016); e 7) Uncorked (trad. Notas de Rebeldia, 2020).

Os títulos selecionados precisavam conter suficientes elementos que permitissem debate, discussão e reflexão pelo tempo proposto para a atividade síncrona (Quadro 1). Buscaram-se, antes de tudo, os elementos técnicos da viticultura e da enologia que pudessem ser explorados, mas cada um dos roteiros permitiu que se trabalhassem diversos outros aspectos, dando abertura a discussões de âmbito relevante para a sociedade, tais como temáticas presentes na Agenda 2030 e nos Objetivos do Desenvolvimento Sustentável (ODS) propostos em 2015 na assembleia geral da Organização das Nações Unidas (ONU). Desde 2019, o IFSC é signatário dos ODS, e a Extensão é a esfera institucional em que afloram oportunidades de explorar a transversalidade entre as áreas do conhecimento. Acredita-se que a atividade, ao propor essa estratégia de intercruzar caminhos entre conteúdos e campos de ciências, pudesse contribuir para um aprendizado significativo, explorando a técnica e a tecnologia da viticultura e da enologia, dentro de contextos de época, permeando a própria história, a enografia e a cultura local, que servem como panos-de-fundo para cada um dos roteiros. 
Quadro 1 - Pontos propostos à reflexão em cada um dos roteiros trabalhados

\begin{tabular}{|c|c|}
\hline Roteiro trabalhado & $\begin{array}{c}\text { Código QR para } \\
\text { acesso ao Estudo } \\
\text { Dirigido }\end{array}$ \\
\hline A Walk in the Clouds (trad. Caminhando nas Nuvens, 1995) & 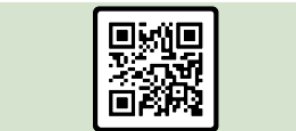 \\
\hline & (2) SCAN ME \\
\hline Bottle Shock (trad. O Julgamento de Paris, 2008) & 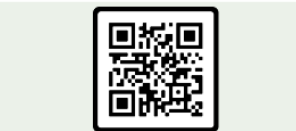 \\
\hline & (8) SCAN ME \\
\hline Sour Grapes (trad. Uvas Azedas, 2016) & 回得回 \\
\hline & (2) SCANME \\
\hline The Secret of Santa Vittoria (trad. O Segredo de Santa Vittoria, 1969) & 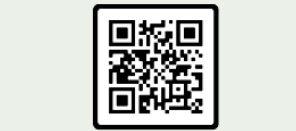 \\
\hline & (8) SCAN ME \\
\hline A Good Year (trad. Um Bom Ano, 2006) & 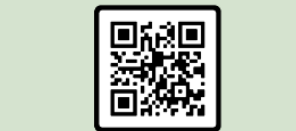 \\
\hline & (2) SCANME \\
\hline The Truth about Alcohol (trad. A Verdade sobre o Álcool, 2016) & 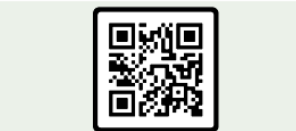 \\
\hline & (8) SCAN ME \\
\hline Uncorked (trad. Notas de Rebeldia, 2020) & 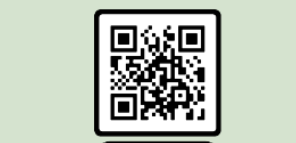 \\
\hline & (2) SCANME \\
\hline
\end{tabular}

Fonte: Elaborado pelas autoras (2021).

\subsection{Divulgação da oferta}

Além da divulgação no Portal Público do Sistema de Informações Gerenciais das atividades de extensão do IFSC (SIGAA-Extensão), a oportunidade foi apresentada nas mídias sociais do IFSC-Câmpus Urupema e compartilhada, a partir dali, pelas mídias pessoais de servidores e de alunos. Também foi solicitado apoio à divulgação para a Associação Brasileira de Enologia (ABE), que compartilhou a oportunidade entre seus associados. 0 período para as inscrições foi de 30 dias. Entre os requisitos para participar, condicionantes para a aprovação, estavam explícitas a necessidade de acesso à internet e a frequência mínima de $75 \%$ durante os encontros síncronos. Embora o curso não propusesse o consumo de bebida alcoólica de nenhuma forma, o fato de dialogar sobre 
elementos da produção do vinho também colocou o requisito da maioridade como condicionante à inscrição, por decisão da coordenação da ação de extensão.

\section{RESULTADOS E DISCUSSÃO}

Para o voluntariado discente, houve duas candidaturas: uma aluna do Curso Técnico em Agricultura (CTA) e uma do Curso Superior em Viticultura e Enologia (CSTVE). Como forma de proporcionar o intercâmbio de ideias entre discentes de cursos e de níveis distintos, as duas inscrições foram aceitas. As discentes contribuíram na interação com os participantes, na discussão prévia dos filmes com a professora, trazendo ideias para a elaboração dos estudos-dirigidos enviados aos participantes, na tabulação e na análise de dados, além de participarem, salvo alguma eventualidade momentânea de conexão, de todos os momentos síncronos.

Figura 4 - Distribuição territorial dos inscritos (a) e aproveitamento das vagas ofertadas (b)
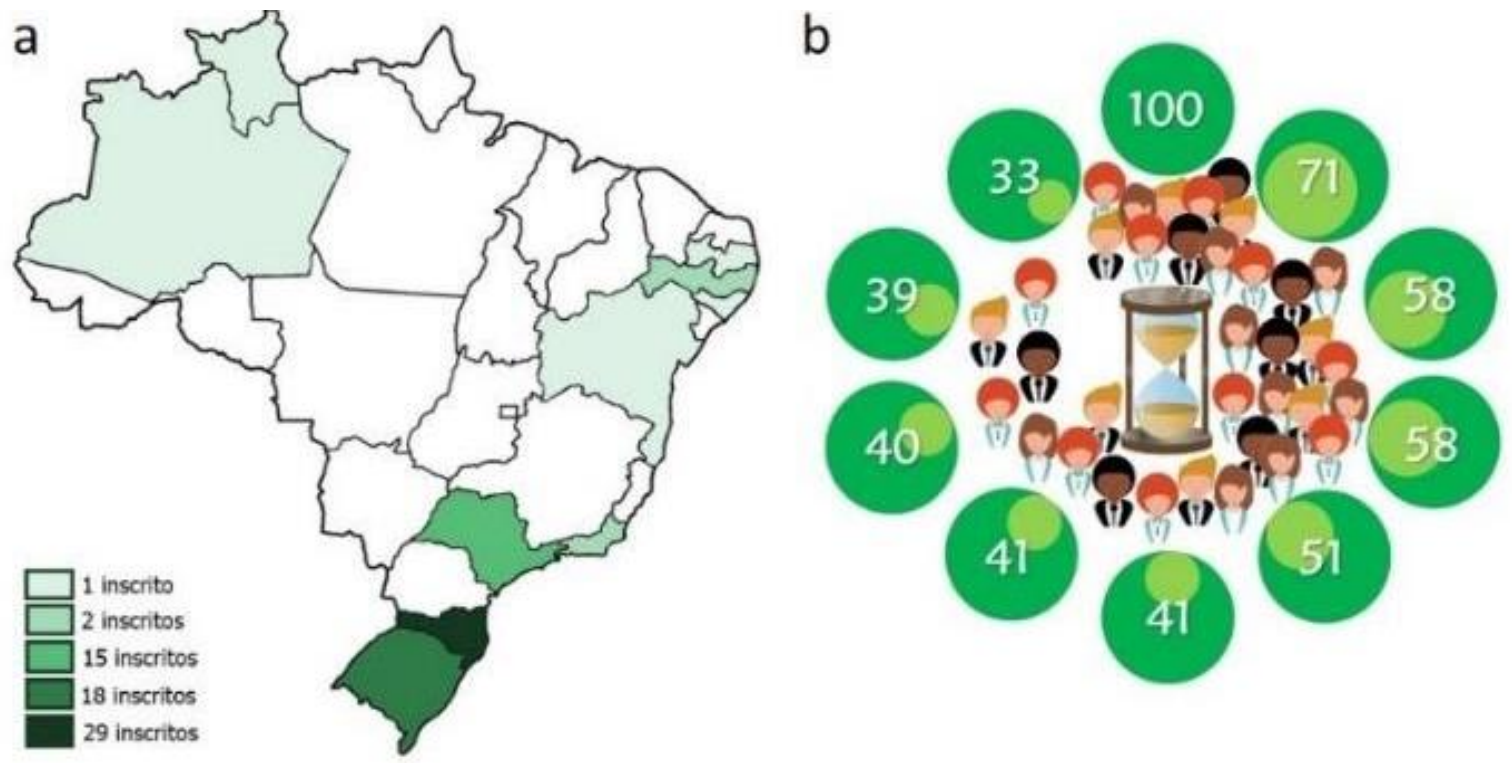

Fonte: Dados desta pesquisa (2021).

Numa análise quantitativa de dados relativos à distribuição territorial dos inscritos e ao aproveitamento de vagas ofertadas (Figura 4), observa-se que mais de dois terços dos inscritos não eram de Santa Catarina (Figura 4a), sendo que Rio Grande do Sul e São Paulo lideraram o número de inscrições. Na posição 12 h (Figura 4b), está o número de vagas ofertadas e, no sentido horário, a quantidade de frequentadores dos encontros propostos no decorrer do curso. Das 100 vagas ofertadas, apenas 71 foram preenchidas. Dos 71 inscritos confirmados, apenas 55 compareceram ao primeiro encontro e apenas 33 alcançaram $75 \%$ de frequência mínima para a conclusão do curso. Pode ser que o 
tempo dado para que as inscrições fossem feitas tenha sido muito curto, ou, mais provavelmente, que a divulgação não tenha sido suficiente. Nesse sentido, é possível que o aproveitamento total das vagas pudesse haver sido alcançado com um prazo maior para a realização das inscrições ou, especialmente, com uma divulgação mais ampla, em que a aposta pelo recompartilhamento, particularmente, a partir desses contatos alcançados em estados brasileiros mais distantes, pudesse criar suas próprias redes de comunicação. Ainda se pode considerar que, embora tenha sido proposto como um curso curto, os oito encontros estenderam-se ao longo de 14 semanas e, quiçá, até pela condição atípica imposta pela situação sanitária, comprometer-se por três meses e meio a uma atividade pode não ter sido, afinal, uma opção tão interessante ou até mesmo viável.

Os canais de divulgação utilizados podem ter contribuído para a distribuição dos participantes ter seguido o padrão de reunir um maior número de interessados provenientes das regiões Sul e Sudeste. Também é possível que o fato de o título da ação de extensão conter a palavra "cinema" possa ter colaborado para despertar o interesse do público dessas regiões, talvez até pela familiaridade com que possivelmente se relacione com essa forma de consumo de cultura. Contudo, destaca-se o fato de algumas inscrições terem partido de estados em que o cinema possa estar ainda incipiente, tais como Roraima, Amazonas, Paraíba e Alagoas.

Figura 5 - Interação dos participantes registrada pelo Mentimeter

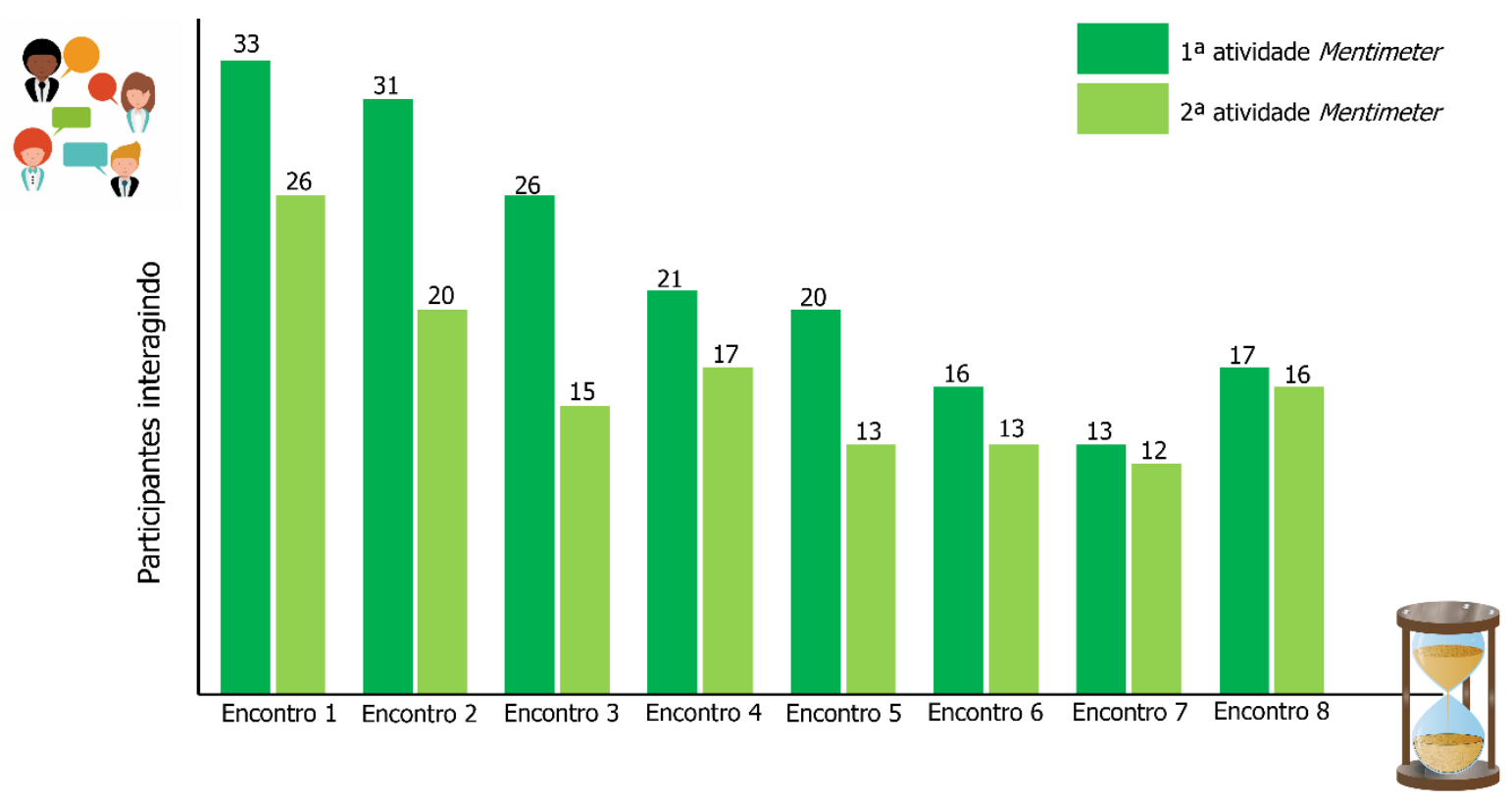

Fonte: Dados desta pesquisa (2021). 
Pelo uso da ferramenta Mentimeter, conseguiu-se avaliar a interação dos participantes com a atividade proposta (Figura 5). Observou-se que houve declínio nas participações do início ao final do curso e, também, entre a primeira e a última meia hora síncrona em cada encontro. Entretanto, de acordo com a estratégia adotada de se lançarem as dinâmicas no início e no final de cada encontro, observa-se que a diferença da permanência durante o encontro resultou ser efetiva no decorrer do curso, com uma menor diferença entre o número de interações da primeira atividade e da última atividade. Em outras palavras, tendo-se, por exemplo, o Encontro 1, sete participantes que interagiram na primeira dinâmica não se apresentaram para a segunda atividade; enquanto, no Encontro 8, apenas um participante não completou $100 \%$ das dinâmicas do dia. Também foi possível se observar aumento no número de interações no último dia do curso, superando o total de registros do sexto encontro. Especula-se como possibilidade para esse acontecimento a hipótese de que alguns participantes necessitavam comparecer ao evento para alcançarem a presença mínima para a certificação, fato este que havia sido reiterado em mensagens enviadas pelas organizadoras no decorrer da última quinzena.

Figura 6 - Retorno (\%) dos formulários encaminhados aos participantes

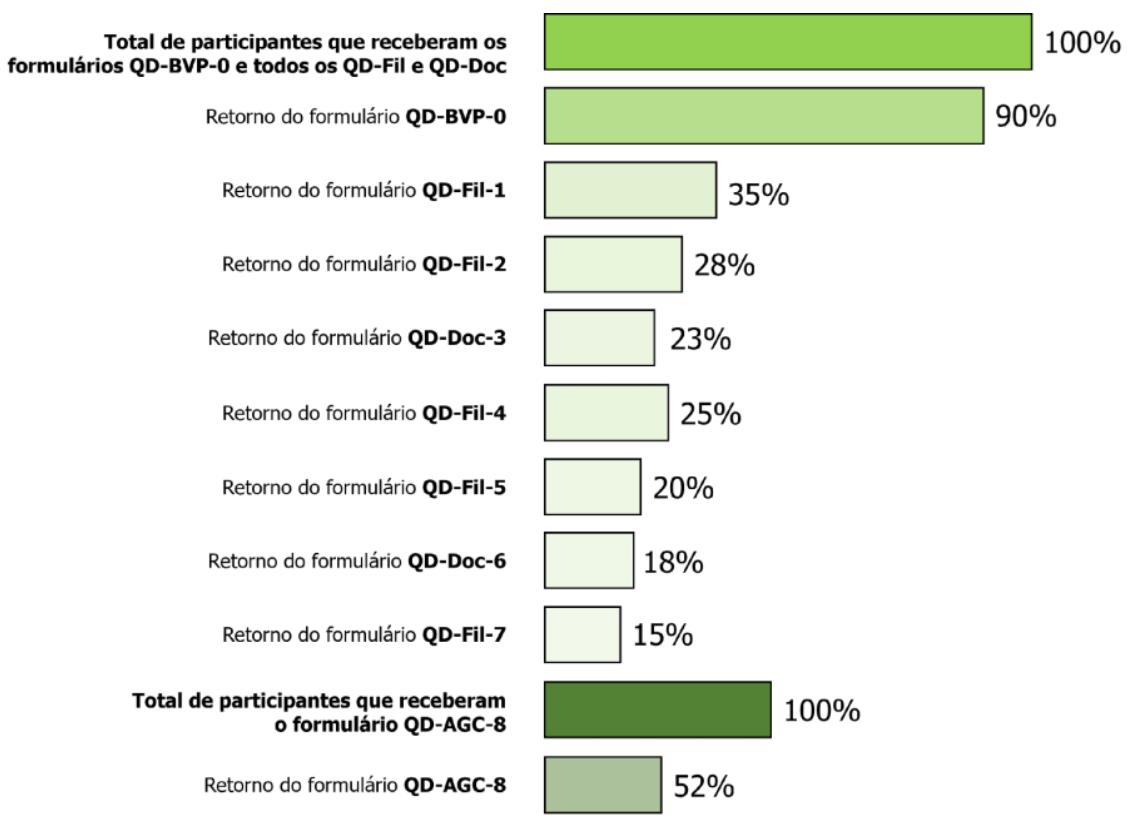

Fonte: Dados desta pesquisa (2021).

Houve 64/71 respostas para o formulário de QD-BVP-0 (Figura 6). A maior parte do público (40/64) se descreveu como "Sou apreciador de bons vinhos e de bons filmes e gostei da proposta do curso". Em relação à pergunta "Qual o seu maior interesse para se inscrever no curso?", 48\% assinalaram a alternativa "todas as anteriores", que incluía 
"aproveitar meu tempo livre", "aprender sobre Viticultura e Enologia", "socializar com enófilos e com cinéfilos". Sobre a pergunta "o que foi mais atrativo na oferta do curso, para 78\% dos respondentes, "O tema do curso (Cinema, Viticultura e Enologia)" foi a resposta, seguida de "A modalidade de oferta do curso (remota)", mais atrativa para 11\% dos respondentes. Sobre a questão relacionada a conhecimentos prévios acerca de viticultura e enologia, $41 \%$ confirmaram a alternativa "um pouco, mas espero aprender mais com esse curso". Para a escolha da plataforma favorita para o desenvolvimento das atividades síncronas, o Google Meet recebeu 73\% das preferências, sendo a ferramenta adotada. Nunca foram alunos de institutos federais $41 \%$ dos respondentes e, para $42 \%$, essa seria a primeira participação em uma atividade de extensão do IFSC.

Houve 17/33 respostas para o formulário QD-AGC-8 (Figura 6). A proposta atendeu muito bem às expectativas de $88 \%$ dos respondentes. Para $77 \%$, os filmes e documentários escolhidos exploraram muito bem a viticultura e a enologia. Em 88\%, o curso despertou muito bem o interesse para aprender mais sobre o referido tema. Para $88 \%$, o curso cumpriu muito adequadamente com o cronograma (dias e horário) previsto. Para 88\%, o material disponibilizado (estudos-dirigidos) pelo curso auxiliou muito bem no acompanhamento das atividades. Para 88\%, o uso da ferramenta Mentimeter auxiliou muito bem no desenvolvimento das atividades. Para 100\%, o uso da plataforma Google Meet auxiliou muito bem no desenvolvimento das atividades. Para 100\%, a equipe organizadora (professora e discentes extensionistas) facilitaram o processo de aprendizagem. Para 88\%, há interesse em uma nova edição do curso oferecido, e 94\% se interessariam por outros cursos de extensão sobre viticultura e enologia.

0 retorno dos formulários sobre os filmes/documentários nunca foi elevado e declinou no decorrer do curso (Figura 6). Apesar do baixo número de devolutivas, foi por meio delas que a equipe executora da ação pôde avaliar a eficácia da estratégia de aprendizagem e de dinâmica adotadas para o curso no decorrer das 14 semanas, permitindo que, sempre que se julgasse necessário, fossem alterados elementos visando atender de forma plena às necessidades dos participantes (Figura 6). A estratégia de adoção dos formulários permitiu uma conexão contínua com a opinião do público participante de forma que eles protagonizassem o direcionamento do êxito da atividade no decorrer dos encontros. Por êxito, buscava-se atingir bons índices de frequência e de interação com, consequentemente, altos índices de aprovação final no curso. Apesar do não aproveitamento integral das vagas ofertadas e do déficit entre o número de inscritos e o número de participantes do primeiro dia, acredita-se que o total de concluintes possa ser considerado satisfatório, com $60 \%$ dos que participaram do primeiro encontro chegando à conclusão da atividade. 
Figura 7 - Percentual de espectadores dos roteiros registrado no Mentimeter

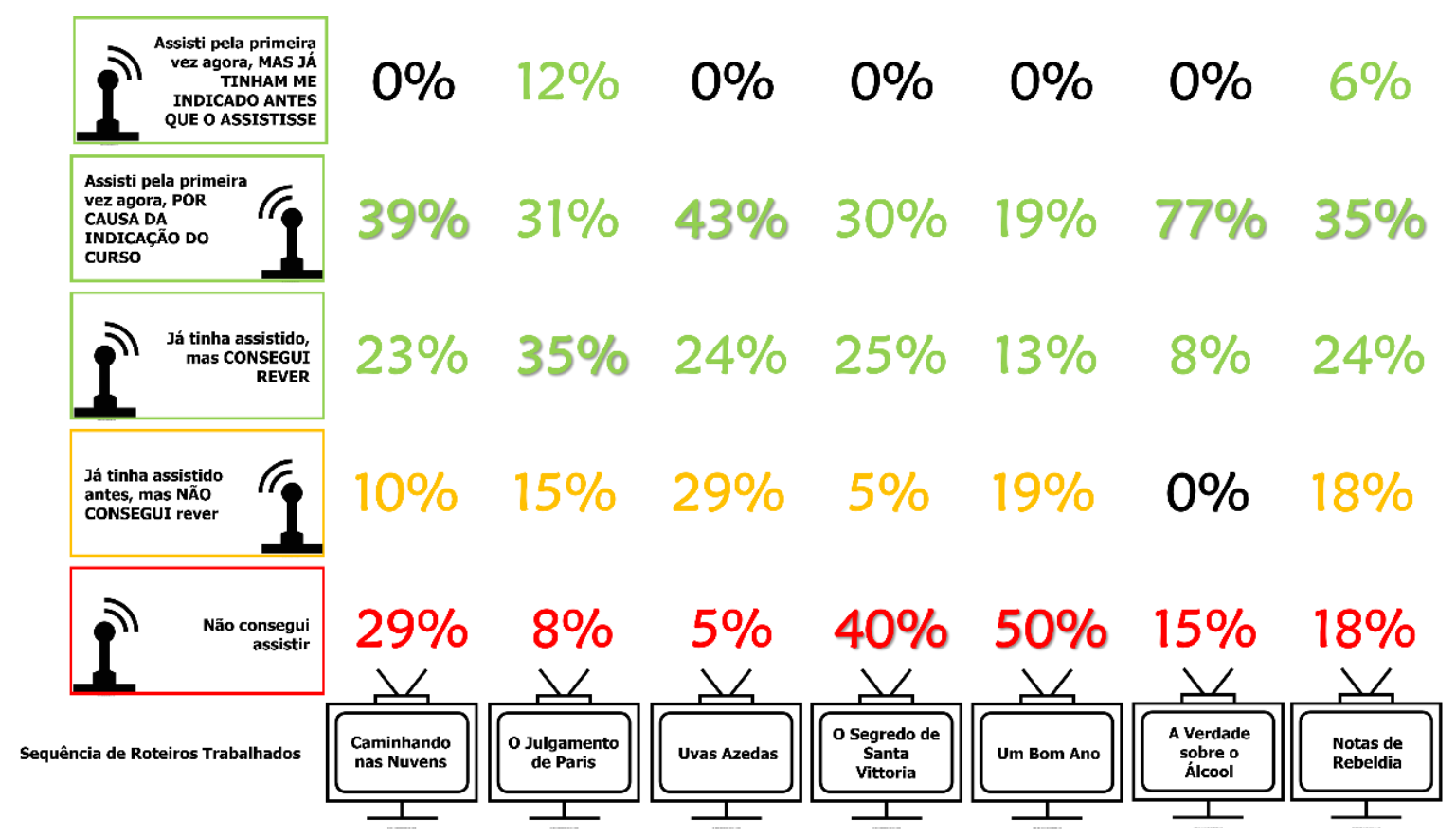

Fonte: Dados desta pesquisa (2021).

Com o Mentimeter, também se soube que aqueles que se dedicaram a assistir aos títulos indicados foram a maioria nos filmes 1, 2, 3, 6 e 7. Também, pôde-se perceber que os filmes 1, 3, 6 e 7 foram assistidos pela primeira vez, por causa da indicação do curso. Destacase ainda que os filmes 4 e 5 foram os que mais devolveram respostas de "não consegui assistir", sendo que, em relação ao filme 5, metade dos participantes declarou não haver conseguido assistir. A audiência voltou a subir com os últimos dois roteiros e, considerandose apenas quem conseguiu ver/rever durante a quinzena de atividades, o filme 6 alcançou a maior audiência (85\%) (Figura 7).

Desde o primeiro encontro, quando fora explicado aos cursantes que assistir ao filme se tratava de algo opcional, e tomou-se essa decisão porque se tinha ciência do fato de o acesso aos filmes não ser uma possibilidade real a todos, imaginava-se que se teria um percentual de pessoas as quais apenas acompanhariam a discussão de forma síncrona, a única contemplada na carga horária do curso. Contudo, não era possível fazer de outra forma, tendo em vista o fato de filmes consistirem em produções artísticas, cuja distribuição ilegal bem como a reprodução não autorizada configuram crime. Trabalhou-se de forma educacional, sempre dentro dos limites previstos pela legislação. A impossibilidade de assistir aos filmes sugeridos não era impeditivo para a participação no curso, mas, evidentemente, ainda que não se tenha sido capaz de identificar desistências do curso diretamente relacionadas a esse motivo, é possível que elas tenham ocorrido. Também não pode ser descartada a hipótese de 
o aproveitamento do curso ter sido maior dentre os participantes comprometidos com as atividades assíncronas, mas pouco se pode inferir sobre esse ponto, pois, apesar de claramente haver comentários muito ricos durante os momentos síncronos, os quais não conseguiriam ser feitos por quem não tivesse acompanhado as exibições dos roteiros, sempre há aquele participante mais reservado, que pouco comenta durante o debate, mas que pode, inclusive, ter se dedicado com mais afinco às atividades assíncronas. Uma avaliação pedagógica mais aprofundada precisaria levar em conta horas dedicadas às atividades assíncronas e, nesse caso, contabilizar esse tempo na certificação também.

Pode-se ainda retornar ao conceito de cineclubismo e analisá-lo do ponto de vista do cenário pandêmico. Para Tarelho (2018), está clara a existência de um público que ainda entenda o cineclubismo como uma mera atividade de entretenimento e lazer, sem compreender o poder transformador intrínseco a esse espaço. Já Lins et al. (2020), justamente debatem a percepção, deformada pela pandemia, do que representa o lazer, pois, uma vez que se parte do princípio de que tempo livre é aquele de que se dispõe quando não se possuem obrigações - laborais, familiares, religiosas, entre outras -, a modificação de hábitos com a rotina de trabalho alterada em tempo e em formato e a recomendação de restrição de convívio em espaços sociais e de priorização das relações nos núcleos familiares, podem ter ocasionado dificuldades de se perceber a existência desse tempo na prática. Também, há que se levar em conta que, durante as 14 semanas pelas quais o curso se estendeu, o país evidenciou uma curva ascendente de propagação do SARS-CoV-2, que culminou com o pico da taxa de óbitos brasileira em abril de 2021. Tendo em vista o agravamento da crise sanitária no Brasil, pode-se pensar que não faltariam justificativas plausíveis para o não engajamento pleno dos participantes com a atividade cineclubista proposta, e se alinha com lins et al. (2020), pois, apesar de quase a metade dos respondentes do QD-BVP-0 incluírem "aproveitar meu tempo livre" entre os seus principais interesses para se inscrever no curso, é difícil rechaçar a ideia de que o tempo livre fora desfigurado pela pandemia.

As nuvens de palavras que retornavam com a segunda dinâmica do Mentimeter (Figura 8) registraram graficamente a mensagem que cada momento síncrono, em que foram trabalhados os filmes e documentários, deixou para os participantes. As nuvens foram organizadas com letras (a-g) que correspondem aos filmes/documentários (1-7). Por meio de algoritmos, é possível construir imagens formadas por vocábulos cujas dimensões indicam sua frequência ou relevância temática no contexto. As cores e fontes também são recursos para facilitar a ênfase da mensagem a ser transmitida. Quanto maior o termo na nuvem, mais vezes ele foi digitado, ou seja, ele é resposta de um maior número de participantes. De todas as palavras registradas, acredita-se que aquelas apresentadas em azul e maiores resumem a 
mensagem do filme/documentário, mostrando que a percepção crítica dos participantes em relação à atividade fora exitosa. Essa dedução é feita porque, no decorrer de cada atividade síncrona, pensamentos e argumentos que poderiam ser resumidos pelas expressões em azul e maiores foram aparecendo na discussão. Dessa forma, o registro dessas palavras, como uma mensagem deixada ao final do debate, mostra tanto a atenção dos participantes durante o momento de interação em conjunto, como o aprendizado sumário do escopo do roteiro. Silva e Jorge (2019) destacam a importância que as nuvens de palavras podem assumir ao expressar sentidos conceituais e sensoriais que se constroem na tentativa de dar sentido a algo intangível, imensurável ou, simplesmente, difícil de ser colocado em um discurso.

Figura 8 - Nuvens de palavras que resumiram a mensagem dos roteiros registrada no Mentimeter.

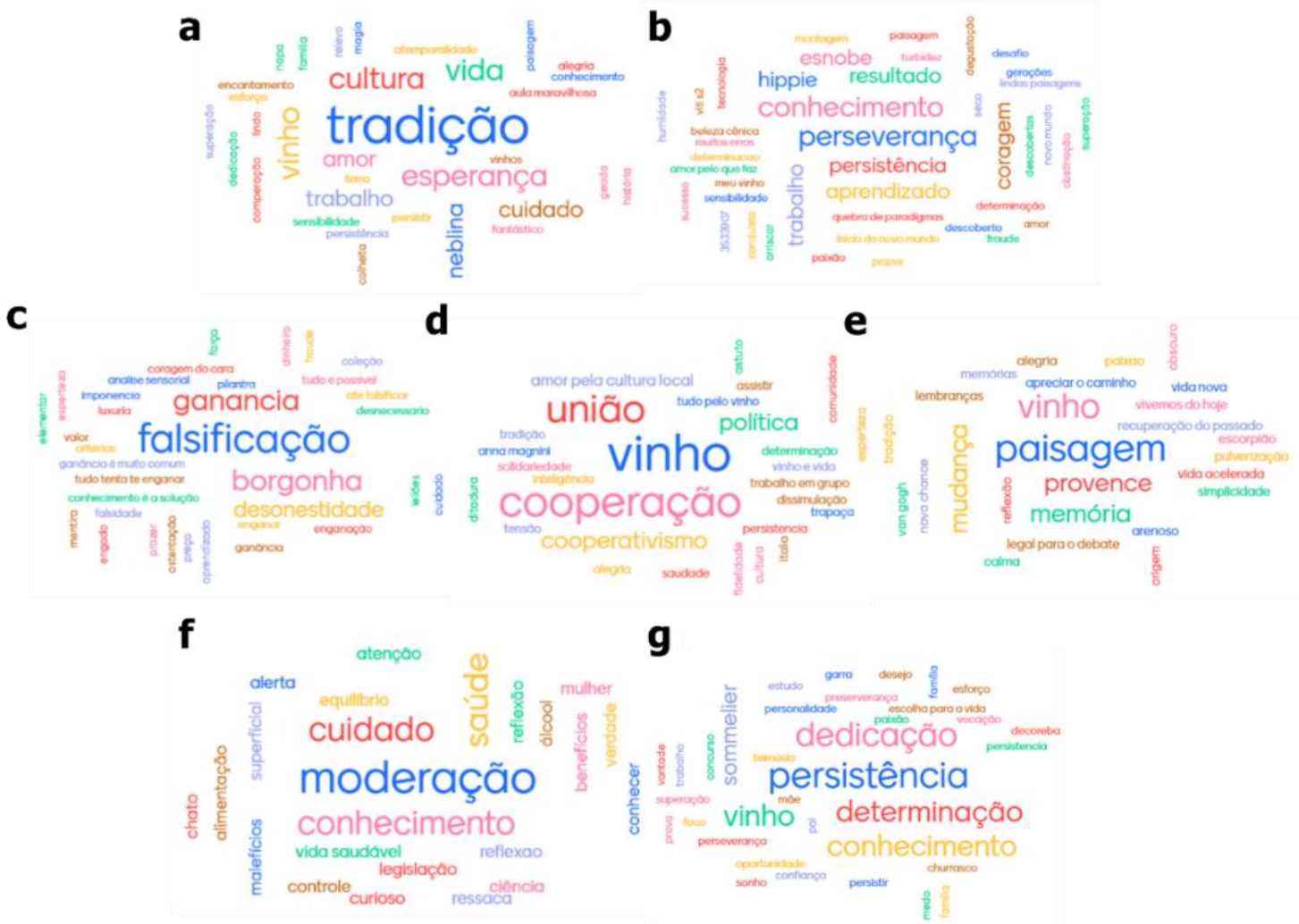

Fonte: Dados desta pesquisa (2021).

Por se tratar de uma atividade de extensão, a transversalidade dos temas é de grande relevância para a caracterização da ação extensionista. E, também, porque foram trabalhados roteiros muito distintos, que retratam civilizações, folclores e costumes próprios, a cultura pode ser considerada a área temática da extensão que genuinamente abrangeu os sete títulos escolhidos (Figura 9). Deu-se a oportunidade de explorar os elementos técnicos da viticultura e da enologia, sem deixar de abordar os contextos históricos que faziam parte de cada um dos roteiros, explorando as tradições de cada um 
dos locais que serviram de cenário para as estórias e contextualizando os aspectos associados aos costumes, às lendas, ao saber-fazer e à história que conecta a videira e o vinho à história da própria humanidade.

Figura 9 - Áreas temáticas da extensão abordadas em cada roteiro escolhido

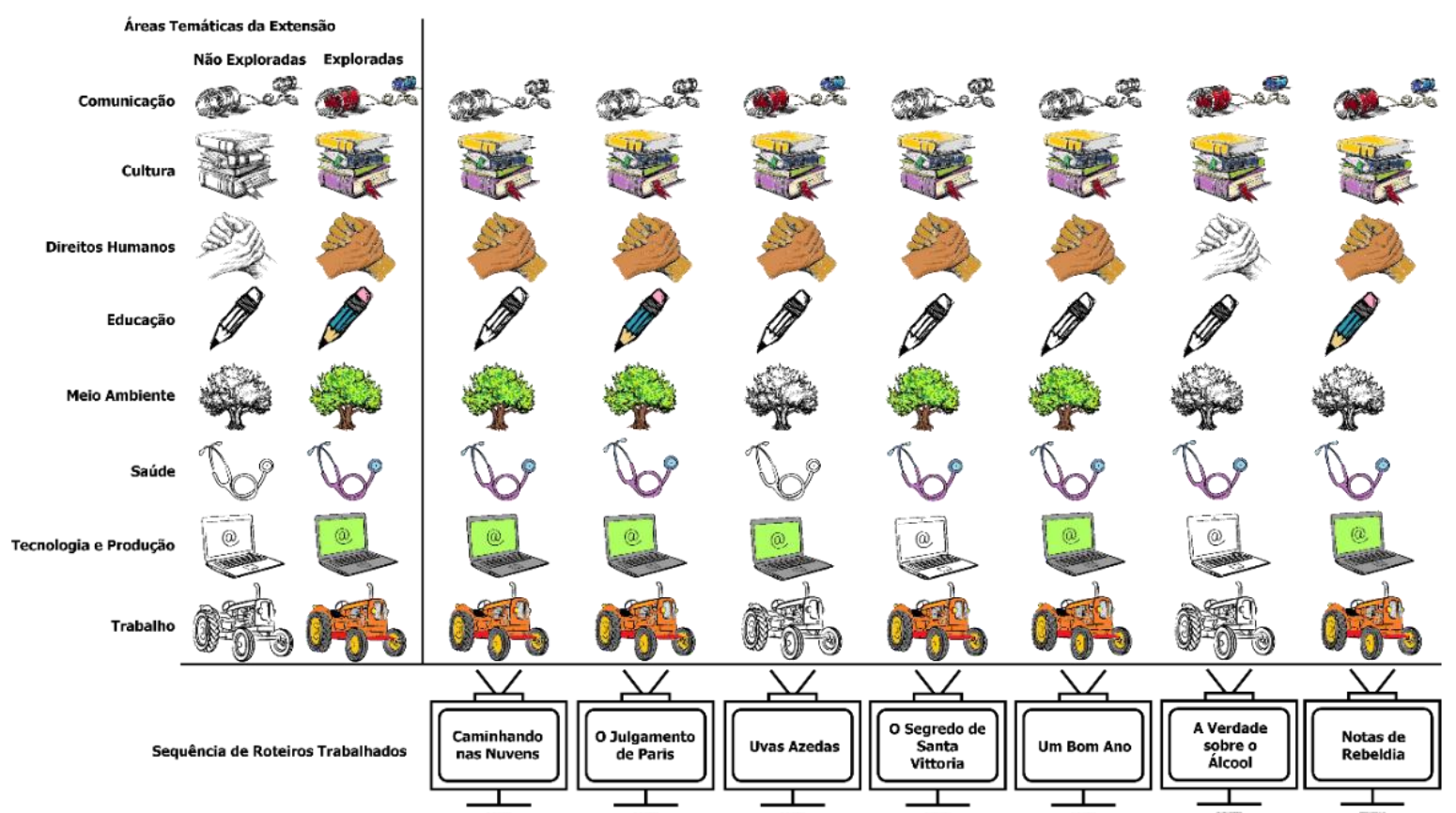

Fonte: Dados desta pesquisa (2021).

O curso consentiu ainda que fossem explorados elementos dentro de cada uma das grandes áreas da extensão, tais como conceitos étnico-raciais e temáticas ligadas à imigração (roteiros 1, 2, 4 e 7), conceitos de igualdade de gênero e de empoderamento feminino (roteiros 2, 3, 4, 5 e 7), conceitos de agricultura sustentável, de energia limpa e renovável, de biodiversidade, de bioprospecção, de cidades e comunidades sustentáveis e resilientes e de mudança global do clima (roteiros 1, 2, 4 e 5), conceitos de saúde e bemestar, de vida saudável, de pandemia, de vacinas e de consciência coletiva (roteiros 1, 2, 4, 5, 6 e 7), conceitos de empreendedorismo, de propriedade intelectual, de uso de imagem e de autorias (roteiros 1, 2, 3, 5 e 7) e, ainda, conceitos de trabalho decente, de crescimento econômico sustentado e sustentável, de produção e consumo responsáveis, de meios de implementação, de ferramentas tecnológicas, de técnicas para a produção, de turismo rural, de agricultura familiar, de agroindústria e de cooperativismo (roteiros 1, 2, 4, 5 e 7) (Figura 9). Os documentários permitiram explorar menos temas transversais; em contrapartida, admitiram abordagens mais profundas na área de tecnologia e produção e da saúde, respectivamente. 
Em todos os formulários, houve espaço para manifestação de opinião, e diversos retornos dados levam a crer que houve aprendizado significativo com a atividade proposta. Como exemplos, traz-se o depoimento da participante Chardonnay, de MaceióAL: "Gostei muito do estudo-dirigido, possibilitou a discussão e compreensão do momento histórico e de alguns vinhedos". Já a participante Nebbiolo, de São Paulo-SP, registrou o seguinte: "Apenas elogiar a dinâmica toda. Tinha dúvida se com o roteiro do filme se conseguiria tirar muita coisa sobre viticultura e enologia, e saiu muito! Além disso, percebe-se o cuidado com a amarração dos materiais e o encontro de sexta. Parabéns!". A participante Malbec, de Bento Gonçalves-RS, fez um longo registro após a dinâmica com o primeiro roteiro:

Fiquei surpresa com tantas áreas do conhecimento que podemos explorar e refletir em cima de um filme. Fiquei surpresa com a informação de que aquele sistema contra a geada é usado até hoje. 0 estudo dirigido e a explanação da professora foram de excelente qualidade, mas penso que ela deva ter cansado de tanto falar. Precisamos interagir mais enquanto grupo, para enriquecer ainda mais a discussão e para não sobrecarregar a professora. 0 grupo é bastante diversificado e essa característica nos faz crescer e aprender mais. (Malbec, Bento Gonçalves-RS).

0 retorno dos formulários sobre os roteiros, no decorrer da atividade, foi primordial nas tomadas de decisões de alteração dos roteiros a serem trabalhados. Essa situação aconteceu devido ao fato de uma das queixas mais recorrentes indicar que os participantes estavam tendo dificuldades para encontrarem os títulos que estavam sendo indicados. Como exemplos, o depoimento da participante Riesling, do Rio de Janeiro-RJ, que não se encabulou de registrar "Um pouco difícil de encontrar, mas valeu a pena a procura, inclusive, ficou até mais interessante!", e de Nebbiolo, de São Paulo-SP, que devolveu: "A dificuldade de encontrar esse filme é incrível! Já havia assistido muitos dos filmes sugeridos, agora este não se encontra pelos meios mais convencionais. Assisti trechos liberados no YouTube; deu para ter uma ideia geral, que se consolidou com a aula.".

0 roteiro 4, "O Segredo de Santa Vittoria", é um filme de 1969, o que possivelmente dificultou que fosse localizado com facilidade. Mas Riesling, que nasceu no ano em que o filme fora lançado, aventurou-se em o buscar para assistir. Talvez para Nebbiolo, uma participante mais idosa (61 anos), os desafios com a procura tenham sido maiores, mas, mesmo assim, o depoimento dela demonstrou que houve dedicação em buscar meios de acompanhar a estória. Outros participantes mencionaram que o tinham visto em algum momento muito anterior de suas vidas, como Tannat, de São José-SC, que registrou "Parabéns pela escolha... [0 filme] é uma verdadeira demonstração de carinho e união e foi uma delícia recordar Bombolini”. "O Segredo de Santa Vittoria” é um clássico 
do cinema, uma estória de um lugarejo pitoresco que produz vinhos na Itália e se passa em meio à própria época da queda do governo fascista de Mussolini. 0 filme figura entre os mais premiados da história do cinema e, além de todo o gabaritado rol de premiações Hollywoodianas, conseguem-se extrair dele grandes aulas de viticultura e de enologia.

A dinâmica com o filme "Um Bom Ano", ocorrida na quinzena seguinte à discussão de o "Segredo de Santa Vittoria", foi a que contou com o menor número efetivo de participações e de interações. Embora o filme fosse mais recente, de 2006, ele não está disponível na Netflix, uma das plataformas de streaming a que os participantes têm mais acesso na atualidade. Nesse romance, julgado "bobo" - apesar da reputação de atores e do diretor - por boa parte dos críticos, percebe-se a celebração da vida e a riqueza da enogastronomia francesa. Puderam-se passar lindos momentos imersos na costa mais rosada de toda a Gália, literalmente! É nessa parte da França mediterrânea que há a conexão mais antiga daquele país com o mundo do vinho. Retornos como o de Riesling, do Rio de Janeiro-RJ, sobre a dinâmica com o roteiro 5, levam a refletir sobre a importância de a iniciativa ter sido proposta durante a pandemia, já que ela desabafa "Um filme para alegrar os corações; um refresco para a alma em meio à situação atual". Riesling, já havia feito manifestação semelhante na dinâmica do filme 1, "Caminhando nas Nuvens":

\footnotetext{
Um filme delicioso de assistir, que traz sentimentos tão raros para os dias atuais, de empatia, de solidariedade, de compreensão, de resiliência, de acolhimento, de cooperação, dentre outros, e, num cenário belíssimo, que são os vinhedos, com toda a tradição da cultura na produção do vinho, como a da família (retratada), de raízes fortes... E, ainda, com um final feliz! Um bálsamo, em tempos de quarentena! (Riesling, Rio de Janeiro-RJ).
}

Depois da dinâmica com "Uvas Azedas", os participantes se sentiram muito provocados em relação ao tema da falsificação de vinhos, e Pinot Noir, de Canoas-RS, considerou "Muito interessante o filme sob vários aspectos: já tinha ouvido falar em "vinho" de abacaxi com corante, para se fazer passar por uva, mas nunca achei que fosse chegar a esse nível [referindo-se ao documentário]!”. A provocação gerada pela discussão do roteiro estendeu-se ao longo da quinzena que se seguiu nos comentários do WhatsApp, e Merlot registrou no formulário: "Gostaria de ressaltar o debate ocorrido no WhatsApp... Foi bem bacana!". o participante Teroldego, de Blumenau-SC, reforçou no formulário que "Se se repetir o curso, esse filme não pode deixar de fazer parte!". Já em relação ao segundo documentário (roteiro 6), que abordava de forma enfática o impacto do álcool para a saúde, o participante Alvarinho, de Bento Gonçalves-RS, registrou que "Não é um filme de experimentação científica, mas consegue dar seu recado sobre os cuidados com o excesso de álcool... A dinâmica foi excelente! A professora fez excelentes explanações muito além do vinho, o que ampliou bastante a fronteira do filme". A devolutiva do participante 
Alvarinho ganha muito significado, tendo em vista que ele é médico angiologista e aspectos do impacto do vinho na saúde cardiovascular foram o enfoque da dinâmica com o documentário "A Verdade sobre o Álcool".

Sobre o formulário QD-AGC-8, Teroldego, de Blumenau-SC, voltou a registrar: “Embora eu não tenha tido condições de participar dos últimos dois encontros, considero que tenha sido uma excelente oportunidade de interagir com a uva e com o vinho por intermédio do cinema". Do Recife-PE, veio o depoimento da participante Glera, que registrou: "Agradeço a oportunidade! Foram ótimos filmes e uma ótima ideia! Vocês arranjaram uma forma dinâmica de espalhar conhecimento. Que venha a parte 2! Kkkk Boas festas!". E a participante Viognier, de Florianópolis-SC, deixou ideias para uma nova edição, registrando que "Gostaria do tema vinho e música ou vinho e pintura, pois a abordagem dos temas transversais interessa-me muito!".

\section{CONCLUSÃO}

As atividades de extensão caracterizam-se por serem um elo importante entre a instituição e a comunidade. Nesta ação, especificamente, conseguiu-se despertar o interesse de um público declaradamente enófilo e cinéfilo, de acordo com as informações registradas no QD-BVP-0. Intriga, contudo, que mais da metade dos títulos escolhidos não haviam sido vistos pelos participantes, mesmo estando incluídos nas listas de roteiros imperdíveis a todo apreciador de vinho e de cinema. Talvez, o cineclubismo, tão presente em outras áreas do conhecimento, precise ser estimulado no que tange à viticultura e à enologia. Da mesma forma, reforçar a tática de unir cinema e ciência com outras atividades de extensão em regiões carentes de educação e cultura, como é o caso de Urupema, na Serra Catarinense, pode permitir à comunidade ocupar, por meio do cinema, espaços democráticos para o exercício pleno de sua cidadania.

O cinema ganha destaque dentre as formas de cultura mais populares. Fazer-se valer de estratégias cineclubistas para, inclusive, introduzir outras artes, como a música, a dança, a poesia, entre tantas outras, ao público, é uma maneira de aliar a ciência técnica e tecnológica às humanidades, tão fundamentais para a formação holística e cidadã. Apesar de a cultura da uva e do vinho há tempos ganhar espaço nos roteiros de cinema, a característica técnicotecnológica que predomina na forma como se ensina a viticultura e a enologia no Brasil pode ter afastado essas ciências de sua essência cultural, política e artística, certamente muito mais presente e recordada naqueles países em que a vitivinicultura é indissociável de seus contextos históricos. O vinho se entrelaça com a história de tal forma como talvez nenhum outro produto o tenha feito (JOHNSON, 2009). No prefácio à segunda edição de seu livro "A 
História do Vinho", Johnson (2009, p. 8) descreve "fazendeiro e artista, servo e sonhador, hedonista e masoquista, alquimista e contador - o viticultor é tudo isso, e assim tem sido desde o Dilúvio". Ainda que se possa questionar o fato de um homem de 800 anos (Noé) ter sido o primeiro viticultor, ao ter plantado uma videira aos pés do monte Ararat e, também, ter sido o primeiro vinhateiro, condenando sua existência à embriaguez proporcionada pelo vinho que aprendeu a fazer ao fermentar suas uvas, não há como se negar a infinidade de registros que trazem a vinha e o vinho representados em pinturas, em esculturas em artefatos ornados, em cenas do cotidiano político, social e religioso nas mais diversas civilizações. Gregos, romanos, egípcios, judeus foram responsáveis por difundir a cultura da uva e do vinho desde a antiguidade; monges cristãos se encarregaram de preservar a vitivinicultura durante o período medieval, enquanto os territórios islâmicos arrancavam os vinhedos e condenavam o consumo do vinho (JOHNSON, 2009). Grandes guerras do mundo podem e são contadas desde a perspectiva daqueles que correram risco de serem mortos ao esconderem sulfato de cobre para poderem tratar as enfermidades de suas vinhas em vez de o entregarem aos exércitos inimigos para que se fizessem munições e armas (KLADSTRUP E KLADSTRUP, 2002). Também podem ser entendidas do ponto de vista daqueles que forjaram papéis contábeis visando ocultar suas negociações clandestinas de vinhos com países declaradamente inimigos (MAZZEO, 2009), ou que mantiveram secretamente seus comércios irregulares em território doméstico, apesar de vigerem proibições de consumo de qualquer bebida alcoólica em seus países (SILER, 2009). Enfim, são inúmeras as evidências que permitem entender os motivos de nenhum outro produto ter com a humanidade relação de tamanha cumplicidade como o vinho o tem, nem de qualquer outra frutífera ser mais cultivada no mundo e se distribuir por todos os continentes, à exceção da Antártida, como a videira. Ignorar o papel cultural que a vinha e o vinho tiveram e têm ao longo da história é rejeitar que a própria técnica e a tecnologia tenham evoluído a partir dessa relação tão próxima entre o homem e suas habilidades de cultivar a videira e dela extrair seus frutos e fermentar seus vinhos.

Recorda-se que a atividade cineclubista envolvendo cinema, viticultura e enologia foi uma ação pioneira para o IFSC-Câmpus Urupema e para a equipe que a executou, buscando atender a uma necessidade urgente e emergente de ofertar cursos em formato remoto em um cenário repleto de incertezas provocado pela condição da pandemia da COVID-19. As dificuldades encontradas no decorrer da execução da atividade de extensão buscaram ser sanadas ou contornadas por meio das muitas interfaces de comunicação que permitiram o diálogo aberto entre a equipe executora e os participantes ao longo das 14 semanas.

Considera-se que os objetivos da atividade foram atingidos, cabendo melhorias, caso se ambicione uma nova edição do curso. Entre os elementos a serem repetidos, porque se 
pondera que tenham alcançado sucesso, estão os títulos escolhidos, os estudos-dirigidos, a plataforma de oferta, a ferramenta de interação do Mentimeter e o grupo do aplicativo WhatsApp. Entre os elementos que devem ter adequação, estão o prazo de divulgação da oferta, o aprimoramento dos canais de divulgação, o acesso aos títulos escolhidos, a objetividade dos formulários e/ou a busca por melhores ferramentas devolutivas.

\section{REFERÊNCIAS}

$A B E$. A vez dos vinhos brasileiros - mundo descobre qualidade e se encanta com diversidade dos rótulos nacionais e reconhecimento dos vinhos tranquilos cresce nos últimos anos. Associação Brasileira de Enologia. Disponível em: https://www.enologia.org.br/noticia/avez-dos-vinhos-brasileiros. Acesso em: 8 fev. 2021.

ANCINE. Agência Nacional de Cinema (ANCINE) divulga números da exibição em 2020-2021. Disponível em: https://www.gov.br/ancine/pt-br/assuntos/noticias/ancine-divulganumeros-da-exibicao-em-2020-e-2021. Acesso em: 2 fev. 2021.

BRASIL. Painel coronavírus em 24 de julho de 2020 - Ministério da Saúde. Disponível em: https://covid.saude.gov.br/. Acesso em: 24 jul. 2020.

BRASIL. Painel coronavírus em 24 de janeiro de 2021 - Ministério da Saúde. Disponível em: https://covid.saude.gov.br/. Acesso em: 24 jan. 2021.

BUTRUCE, Débora. Cineclubismo no Brasil: esboço de uma história. Acervo, Rio de Janeiro, v.16, n.1, p. 117-124, 2011.

IBGE. Malha municipal Brasileira. In: Geociências: Estrutura Territorial - Organização do Território, 2019. Disponível em: https://www.ibge.gov.br/geociencias/organizacao-doterritorio/estrutura-territorial/15774-malhas.html?edicao=15874\&t=acesso-ao-produto. Acesso em: 2 fev. 2021.

JOHNSON, Hugh. A história do vinho: nova edição ilustrada. Tradução: Eliane de Miranda Piereck. 2. ed. São Paulo: CMS Editora, 2009.

KLADSTRUP, Don; KLADSTRUP, Peter. Vinho e Guerra: os franceses, os nazistas e a batalha pelo maior tesouro da França. Rio de Janeiro: Zahar, 2002.

LINS, Cynthia de Freitas Melo; COSTA, Ícaro Moreira; MORAES, Laís Duarte de; BARBOSA JUNIOR, Francisco Welligton de Sousa; MARTINS, José Clerton de Oliveira. Ócio, lazer e tempo livre das velhices em quarentena: perspectivas psicossociais de um estudo brasileiro. Licere, Belo Horizonte, v. 23, n. 3, p. 341-368, 2020. DOI: https://doi.org/10.35699/24476218.2020.25446. 
MASCARELLO, Fernando. (org.). História do cinema mundial. Campinas: Editora Papirus, 2015.

MAZZEO. Tilar J. A viúva Clicquot: a história de um império do champanhe e da mulher que o construiu. Tradução: Angela Lobo. Rio de Janeiro: Rocco, 2009.

MOURA, Eduardo. Brasileiro sente mais falta do cinema e $66 \%$ vão retomar planos culturais, diz estudo. Folha de São Paulo. Disponível em: https://www1.folha.uol.com.br/ilustrada/2020/10/brasileiro-sente-mais-falta-docinema-e-66-vao-retomar-planos-culturais-diz-estudo.shtml. Acesso em: 4 fev. 2021.

OCA-ANCINE. Observatório Brasileiro do Cinema e do Audiovisual. Agência Nacional do Cinema, 2018. Disponível em: https://oca.ancine.gov.br/paineisinterativos?painel=viz1558970268340. Acesso em: 1 fev. 2021.

SCHVARZMAN, Sheila. Cinema, literatura e sociedade - História e historiografia do cinema Brasileiro: objetos do historiador. Especiaria: Cadernos de Ciências Humanas, Santa Cruz do Sul, v. 10, n. 17, p.15-40, 2007.

SILER, Julia Flynn. Casa Mondavi: ascenso e queda de uma dinastia do vinho. Tradução: Adriana Kuffer Rundle. Revisão da tradução: Marcela Miller. Rio de Janeiro: G. Ermakoff Casa Editorial, 2009.

SILVA, Paulo Vasconcellos.; JORGE, Tania Araújo. Análise de conteúdo por meio de nuvem de palavras de postagens em comunidades virtuais: novas perspectivas e resultados preliminares. Atas - Investigação Qualitativa em Saúde/Investigación Cualitativa en Salud, v. 2, p. 41-48, 2019. Apresentado no 8o Congresso Ibero-Americano em Investigação Qualitativa, 2019, Lisboa, Portugal.

TARELHO, Weliton Alécio. Cineclubismo como atitude crítica e sua urgência. Revista do NESEF, Filosofia e Ensino, Curitiba, v.7, n.1, p. 98-104, 2018. DOI:

http://dx.doi.org/10.5380/nesef.v7i1.62488.

VARGAS, João Carlos Martini de; LOPES, Leticia Azambuja. O ensino de ciências e a franquia Star Wars: possibilidades pedagógicas, e-Mosaicos, Rio de Janeiro, v. 9, n. 22, p. 236-250, 2020. DOI: https://doi.org/10.12957/e-mosaicos.2020.45268

\section{FILMOGRAFIA}

A GOOD YEAR. Direção: Ridley Scott. Roteiro: Mark Klein. Reino Unido/Estados Unidos, 2006. Apple TV (1h 58min).

A WALKING IN THE CLOUDS. Direção: Alfonso Arau. México/Estados Unidos, 1995. DVD (1h $42 \mathrm{~min})$. 
BOTTLE SHOCK. Direção: Randall Miller. Roteiro: Jody Savan; Randall Miller; Ross Schwartz. Estados Unidos, 2008. YouTube (1h 50min).

SOUR GRAPES. Direção: Jerry Rothwell; Reuben Atlas. Roteiro: Al Morow; Catherine Siméon. Reino Unido, 2016. Netflix (1h 15min).

THE SECRET OF SANTA VITTORIA. Direção: Stanley Kramer. Estados Unidos, 1969. DVD (2h 19min).

THE TRUTH ABOUT ALCOHOL. Direção: David Briggs. Roteiro: David Briggs. Reino Unido, 2016. Netflix (58 min).

UNCORKED. Direção: Prentice Penny. Roteiro: Prentice Penny. Estados Unidos, 2020. Netflix (1h 44min).

Os autores declaram participação na autoria conforme a Taxonomia CRediT da Casari (vide https://casrai.org/)

\begin{tabular}{|c|c|c|c|c|c|c|}
\hline Conceituação & Metodologia & Software & Validação & Análise formal & Investigação & Recursos \\
\hline$[1]$ & {$[1] /[2] /[3]$} & Não se aplica & {$[1] /[2] /[3]$} & {$[1]$} & {$[1] /[2] /[3]$} & {$[1]$} \\
\hline Curadoria & Primeira redação & Revisão/edição & Visualização & Supervisão & Admin. projeto & Financiamento \\
\hline$[1] /[2] /[3]$ & {$[1]$} & {$[1]$} & {$[1] /[2] /[3]$} & {$[1]$} & {$[1]$} & Não se aplica \\
\hline
\end{tabular}

